\title{
Profile of Pregnant Women with Gestational Diabetes Mellitus at Increased Risk for Large for Gestational Age Newborns
}

\section{Perfil de gestantes com Diabetes Mellitus Gestacional com maior risco para recém-nascidos grandes para a idade gestacional}

\author{
Maria da Glória Rodrigues Tavares ${ }^{10}$ Érika Sales Lopes ${ }^{1}$ Rosy Anne de Jesus Pereira Araújo Barros ${ }^{2}$ \\ Rossana Santiago de Sousa Azulay ${ }^{1}$ Manuel dos Santos Faria ${ }^{1}$

\footnotetext{
${ }^{1}$ Endocrinology Unit of University Hospital, Universidade Federal do Maranhão, São Luís, MA, Brazil

2 Department of Obstetrics and Gynecology, Universidade Federal do Maranhão, São Luís, MA, Brazil
} \\ Address for correspondence Maria da Glória Rodrigues Tavares, MsC, \\ Rua Almirante Tamandaré, 1, 65020-600, Centro, São Luís, MA, Brasil \\ (e-mail: madagloria@gmail.com).
}

Rev Bras Ginecol Obstet 2019;41:298-305.

\begin{abstract}
Keywords

- gestational diabetes mellitus

- oral glucose tolerance test

- large for gestational age
\end{abstract}

Resumo
Objective Gestational diabetes mellitus (GDM) is associated with a higher risk of perinatal morbidity and mortality, and its main complication is the occurrence of large for gestational age (LGA) newborns. The present study aims to characterize pregnant women with GDM and to identify factors associated with the occurrence of LGA newborns in this population.

Methods A cross-sectional study was performed based on medical records of women whose prenatal care and delivery were performed the Maternal and Child Unit of the Hospital Universitário of the Universidade Federal do Maranhão, state of Maranhão, Brazil. A total of 116 pregnant women diagnosed with GDM were included according to the criteria of the International Association of Diabetes and Pregnancy Study Groups (IADPSG).

Results The variables associated with LGA newborns after multivariate analysis were: obesity prior to pregnancy ( $\mathrm{OR}=11.6 ; 95 \% \mathrm{Cl}: 1.40-95.9$ ), previous macrosomia (OR $=34.7 ; 95 \% \mathrm{Cl}: 4.08-295.3)$, high blood glucose levels in the $3^{\text {rd }}$ trimester $(\mathrm{OR}=2,67 ; 95 \%$ Cl: 1.01-7.12) and combined change in the oral glucose tolerance test (OGTT) (fasting + postdextrose) $(\mathrm{OR}=3.53 ; 95 \% \mathrm{Cl}: 1.25-14.2)=1.17-10.6)$. Otherwise, insufficient weight gain during pregnancy reduced the risk for $L G A$ newborns ( $O R=0.04 ; 95 \% \mathrm{Cl}: 0.01-0.32$ ). Conclusion Obesity prior to pregnancy, previous macrosomia, high blood glucose levels in the $3^{\text {rd }}$ trimester, and combined change in the OGTT were independent predictive factors for LGA newborns in pregnant women with GDM.

Objetivo Diabetes mellitus gestacional (DMG) está associado a um maior risco de morbidade e mortalidade perinatais, e sua principal complicação é a ocorrência de

(1) Maria da Glória Rodrigues Tavares's ORCID is https://orcid.org/ 0000-0001-6531-0227.

received July 6, 2018 accepted

March 7, 2019
DOI https://doi.org/ $10.1055 / \mathrm{s}-0039-1687860$ ISSN 0100-7203.
Copyright $\odot 2019$ by Thieme Revinter Publicações Ltda, Rio de Janeiro, Brazil
License terms

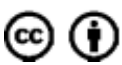




\section{Palavras-chave}

- diabetes mellitus gestacional

- teste oral de tolerância à glucose

- grande para idade gestacional recém-nascidos grandes para idade gestacional (GIG). O presente estudo visa caracterizar as gestantes com DMG e identificar fatores associados à ocorrência de recémnascidos GIG nesta população.

Métodos Estudo transversal realizado a partir da coleta de dados de prontuário de mulheres cujo acompanhamento pré-natal e parto foram realizados na Unidade Materno-Infantil do Hospital Universitário da Universidade Federal do Maranhão, MA, Brasil. Foram incluídas 116 gestantes diagnosticadas com DMG pelo critério do International Association of Diabetes and Pregnancy Study Groups (IADPSG).

Resultados As variáveis associadas à GIG após análise multivariada foram: obesidade pré-gestacional (OR=11,6; IC 95\%: 1,40-95,9), macrossomia anterior (OR = 34,7; IC 95\%: 4,08-295,3), glicemia em jejum elevada no $3^{\circ}$ trimestre $(\mathrm{OR}=2,67$; IC 95\%: 1,01-7,12) e alteração combinada no teste de tolerância oral à glicose (jejum + pósdextrose) $(O R=3,53 ; \mathrm{IC} 95 \%: 1,17-10,6)$. Ganho de peso inferior reduziu o risco para GIG (OR=0,04; IC 95\%: 0,01-0,32).

Conclusão Obesidade anterior à gestação, macrossomia prévia, níveis elevados de glicose no sangue no $3^{\circ}$ trimestre e alteração combinada no TOTG foram fatores preditivos independentes para os recém-nascidos GIG em gestantes com DMG.

\section{Introduction}

Gestational diabetes mellitus (GDM) is classically defined as glucose intolerance resulting in hyperglycemia of variable intensity, with onset or first recognition during pregnancy, which may or may not persist after childbirth. ${ }^{1}$

Gestational diabetes mellitus is usually diagnosed through provocative tests using glucose loads. In 2010, the International Association of Diabetes and Pregnancy Study Groups (IADPSG) suggested a new diagnostic criteria based on the $75 \mathrm{~g}$ oral glucose tolerance test (75-g OGTT) - performed between 24 and 28 weeks of gestation, with plasma glucose measured at baseline (fasting), after 1 hour, and after 2 hours, wherein one altered measurement (fasting plasma glucose $\geq 92 \mathrm{mg} / \mathrm{dL} ; 1$ hour $\geq 180 \mathrm{mg} / \mathrm{dL} ; 2$ hour $\geq 153 \mathrm{mg} / \mathrm{dL}$ ) is sufficient for the diagnosis of GDM. ${ }^{2}$ The American Diabetes Association (ADA) endorsed this diagnostic criteria in 2011, and 2 years later, the World Health Organization (WHO) revised and updated this criteria and introduced the recommendations of the IADPSG. ${ }^{3,4}$ Currently, the Brazilian Society of Diabetes and the Brazilian Federation of Gynecology and Obstetrics Associations, similar to the ADA and the WHO, use the same criteria for the diagnosis of GDM. ${ }^{5}$

The prevalence of GDM is quite variable, depending on the population under study and on the diagnostic criteria. According to the IADPSG criteria, the prevalence of GDM significantly increased by up to between 15 and $20 \%{ }^{2}$ In addition to being related to changes in the diagnostic criteria, this increase is also related to the increasing prevalence of obesity (body mass index [BMI] $\geq 30 \mathrm{~kg} / \mathrm{m}^{2}$ ), which itself is a risk factor for the onset of GDM. ${ }^{6}$ The risk of developing GDM is estimated to be 2,4 , and 8 times greater in overweight, obese, and morbidly obese women, respectively, than in women of healthy weight. ${ }^{7}$ Thus, the higher the degree of maternal obesity, the greater the risk of developing GDM, primarily because of insulin resistance., ${ }^{7,8}$
Gestational diabetes mellitus is associated with a high risk of perinatal morbidity and mortality, and the main complication is macrosomia or large for gestational age (LGA) fetuses. ${ }^{9}$ Macrosomia is defined as birth weight $>4,000 \mathrm{~g}$; however, this definition fails to consider gestational age (GA). Large for gestational age corresponds to birth weight $\geq 90^{\text {th }}$ percentile for the corresponding GA. ${ }^{10}$

Fetal macrosomia is clinically relevant because it poses risks both for the mother as well as for the fetus. Maternal complications are often related to fetal-pelvic disproportion, prolonged labor, soft-tissue lacerations, high rates of cesarean section, postpartum hemorrhage, and placental retentions arising from uterine atony. ${ }^{9}$ It is also associated with perinatal morbidity and mortality; the fetal injuries most commonly associated with macrosomia and shoulder dystocia are fracture of the clavicle and damage to the nerves of the brachial plexus, which can produce Erb paralysis. ${ }^{11}$

The literature features substantial variations in factors that increase the probability of macrosomia with respect to the extent of the association between risk factors and excessive birth weight, with the true role of the several factors involved in the genesis of this complication remaining undefined. Fetal macrosomia is related to advanced maternal age, maternal diabetes and glucose intolerance, post-term pregnancy, excessive weight and obesity prior to pregnancy, male fetus, multiparity, excessive weight gain (EWG) during pregnancy, parental height, and an obstetric history of macrosomia. ${ }^{12,13}$

The most common and well-described pathogenic mechanism of accelerated fetal growth is related to maternal diabetes mellitus. In maternal hyperglycemia, excess glucose crosses the placenta and reaches the fetal circulation, thereby stimulating fetal insulin secretion. Hyperinsulinemia and excess glucose in utero favors insulin-sensitive tissue hypertrophy, promoting accelerated growth that may lead to macrosomia. $^{14}$ 
To characterize the profile of pregnant women with GDM who are at a higher risk of presenting complications caused by excessive fetal growth, the present study seeks to identify risk factors associated with LGA newborns in this population.

\section{Methods}

A cross-sectional study was conducted at the Maternal and Child Unit of the Hospital Universitário of the Universidade Federal do Maranhão, state of Maranhão, Brazil, using information from medical records. The research protocol was approved in advance by the local Research Ethics Committee (opinion number: 1451033).

The present study included pregnant women with GDM diagnosed by OGTT using the IADPSG criteria, whose monitoring and delivery had taken place at the HUMI between January 2015 and December 2017. The exclusion criteria were: pregnant women with plasma glucose $\geq 126 \mathrm{mg} / \mathrm{dl}$ during the $1^{\text {st }}$ trimester; previous diagnosis of chronic hypertension and collagen diseases; human immunodeficiency virus, hepatitis B or hepatitis $\mathrm{C}$ infection; newborns hospitalized in a neonatal intensive care unit (ICU); fetal malformation; and twin pregnancies. The data were collected from maternal and neonatal electronic medical records.

The variables studied were the following: maternal age in whole years, categorized as $<35$ years old or $>35$ years old; maternal height in centimeters; prepregnancy BMI estimated using the Quetelet index and classified according to the Food and Agriculture Organization (FAO)/WHO criteria; gestational weight gain (WG) estimated by the difference between maternal weight at delivery and the usual weight prior to the pregnancy reported at the $1^{\text {st }}$ prenatal visit. ${ }^{15,16}$ Weight gain was classified according to the Institute of Medicine (IOM) criteria as insufficient (IWG), appropriate (AWG) and EWG. ${ }^{17}$ The investigation also included the following: a family history of diabetes among first-degree relatives; obstetric history, including parity, previous pregnancy with macrosomia, and a previous history of GDM; OGTT values upon diagnosis; and blood sugar levels throughout the $3^{\text {rd }}$ trimester, using the arithmetic mean of capillary blood glucose levels while fasting and 2 hours after breakfast, routinely measured at every visit.

The studied characteristics of the newborns were the following: birthweight, gender, type of delivery, and GA. Birthweight was corrected for GA based on the recent recommendations suggested by the Intergrowth study, and it was used to analyze the calculated percentile values with the aid of this tool. ${ }^{18}$ Based on calculated percentile values, the newborns were classified as small for gestational age (SGA, weight $<10^{\text {th }}$ percentile), appropriate for gestational age (AGA, $10^{\text {th }}$ percentile $<$ weight $<90^{\text {th }}$ percentile), or LGA (weight $>90^{\text {th }}$ percentile). ${ }^{10}$ Macrosomia was defined as birth weight $\geq 4,000 \mathrm{~g}$, regardless of the GA. ${ }^{10}$

Data were processed using the software PASW Statistics for Windows, Version 18.0 (SPSS Inc., Chicago, IL, USA). Initially, a descriptive statistical analysis was performed by estimating frequency, mean, and standard deviation (SD). The normality of quantitative variables was tested using the Lilliefors test. Subsequently, analysis of variance (ANOVA) with the post-hoc
Tukey test was used for the comparative analysis of numerical variables. The distribution of categorical variables was analyzed using the chi-squared test or the Fisher exact test. Odds ratio (OR) and 95\% confidence intervals (Cls) were used to assess the association with the LGA outcome. A multivariate logistic regression model was built to estimate the ORs adjusted for variables presenting $a p$-value $<0.10$ in the bivariate analysis. Variables related to glycemia parameters were not adjusted to avoid multicollinearity. In addition, receiver operating characteristic (ROC) curves were analyzed to estimate the area under the curve (AUC), and a $95 \% \mathrm{CI}$ was established to predict LGA newborns using OGTT levels (at 0, 60, and 120 minutes). The significance level adopted for all of the analyses was of $5 \%$.

\section{Results}

In total, 116 pregnant women with GDM were included in the present study. The mean age was $32.7 \pm 6.4$ (range: 18 44) years old; $41.1 \%$ of the women had a family history of diabetes among their first-degree relatives, and $25 \%$ were multiparous. The mean GA at delivery was $38.1 \pm 1.5$ weeks, with a cesarean section rate of $75 \%$. The overall occurrence of LGA newborns was of $25.9 \%$.

With regard to prepregnancy BMI, 28\% (32/116), 31\% (35/ $116)$, and $43 \%$ (49/116) of the women had normal weight, were overweight, and were obese, respectively. Considering the IOM recommendations for WG during pregnancy, $~ 35 \%$ of the pregnant women had EWG, with a similar percentage being observed for WG in each prepregnancy BMI category (-Table 1). Large for gestational age newborns were more frequent in overweight and obese women. Macrosomia was only more frequent in the group of mothers who were obese before pregnancy (-Table 2). Only four women had SGA newborns and, of these, only one had insufficient WG during pregnancy.

The mean GA when OGTT was conducted was 25 weeks. At the time of the test, $\sim 13 \%$ of the diagnoses were because of changes only in fasting plasma glucose, and $50.9 \%$ were because of changes in both fasting and post-dextrose load. The mean fasting plasma glucose level at the time of the test was higher in the group of pregnant women who were overweight and obese prior to the pregnancy ( - Table 1 ).

With regard to treatment, $\sim 43 \%$ of the pregnant women received only insulin as a medical therapy during pregnancy. Blood glucose levels were monitored during the $3^{\text {rd }}$ trimester, and the mean fasting blood glucose level was higher in the group of women who were obese prior to the pregnancy (-Table $\mathbf{1}$ ).

The percentage of LGA newborns was statistically higher among women with overweight, with obesity, with a previous history of macrosomia, with high mean fasting blood glucose in the $3^{\text {rd }}$ trimester, with changes in 3 OGTT measurements, and with a combined change in the OGTT (fasting + after dextrose load). In women with IWG during pregnancy, the percentage of LGA newborns was statistically lower. After the multivariate analysis, the following factors were associated with LGA newborns: obesity (OR $=11.6$; $95 \%$ CI: $1.40-95.9$ ), previous macrosomia ( $\mathrm{OR}=34.7$; 95\% CI: 4.08-295.3), high 
Profile of Pregnant Women with Gestational Diabetes Mellitus Tavares et al. 301

Table 1 Description of maternal and obstetric data according to pre-gestational body mass index

\begin{tabular}{|c|c|c|c|c|c|}
\hline \multirow[t]{2}{*}{ Variables } & \multirow{2}{*}{$\begin{array}{l}\text { Total } \\
n=116\end{array}$} & \multicolumn{3}{|c|}{ Pre-gestational BMI } & \multirow[t]{2}{*}{ p-value } \\
\hline & & $\begin{array}{l}\text { Normal } \\
n=32\end{array}$ & $\begin{array}{l}\text { Overweight } \\
n=35\end{array}$ & $\begin{array}{l}\text { Obesity } \\
n=49\end{array}$ & \\
\hline Age (years old) & $32.7 \pm 6.4$ & $30.9 \pm 7.1$ & $33.6 \pm 5.4$ & $33.2 \pm 6.3$ & 0.158 \\
\hline Height(cm) & $156 \pm 6$ & $156 \pm 7$ & $155 \pm 5$ & $157 \pm 5$ & 0.178 \\
\hline Multiparous (\%) & $25.0 \%$ & $12.5 \%$ & $20.0 \%$ & $36.7 \%$ & 0.101 \\
\hline Weigth gain $(\mathrm{kg})$ & $9.5 \pm 6.9$ & $12.9 \pm 5.3$ & $9.5 \pm 6.4$ & $7.3 \pm 7.4^{* *}$ & $0.001^{*}$ \\
\hline Categories of weigth gain (\%) & & & & & 0.731 \\
\hline Insufficient & $33.6 \%$ & $40.6 \%$ & $37.1 \%$ & $26.5 \%$ & \\
\hline Appropriate & $31.0 \%$ & $28.1 \%$ & $28.6 \%$ & $34.7 \%$ & \\
\hline Excessive & $35.4 \%$ & $31.3 \%$ & $34.3 \%$ & $38.8 \%$ & \\
\hline \multicolumn{6}{|l|}{ OGTT values $(\mathrm{mg} / \mathrm{dl})$} \\
\hline Fasting & $95.6 \pm 14.6$ & $89.6 \pm 12.0$ & $98.2 \pm 16.9^{* *}$ & $97.6 \pm 13.3^{* *}$ & $0.021^{*}$ \\
\hline 60 minutes & $187.8 \pm 34.5$ & $184.7 \pm 31.0$ & $198.1 \pm 42.2$ & $183.0 \pm 30.1$ & 0.202 \\
\hline 120 minutes & $172.1 \pm 35.1$ & $160.4 \pm 31.3$ & $185.8 \pm 36.4^{* *}$ & $169.7 \pm 33.7$ & $0.009^{*}$ \\
\hline Number of points changed in OGTT (\%) & & & & & 0.255 \\
\hline 1 point & $37.1 \%$ & $53.1 \%$ & $28.6 \%$ & $32.6 \%$ & \\
\hline 2 points & $37.9 \%$ & $31.3 \%$ & $42.8 \%$ & $38.8 \%$ & \\
\hline 3 points & $25.0 \%$ & $15.6 \%$ & $28.6 \%$ & $28.6 \%$ & \\
\hline Categories changed in OGTT & & & & & 0.084 \\
\hline Only fasting & $12.9 \%$ & $18.7 \%$ & $5.7 \%$ & $14.3 \%$ & \\
\hline Only after dextrose load & $36.2 \%$ & $50.0 \%$ & $34.3 \%$ & $28.6 \%$ & \\
\hline Fasting and after dextrose load & $50.9 \%$ & $31.3 \%$ & $60.0 \%$ & $57.1 \%$ & \\
\hline Insulin therapy (\%) & $43.1 \%$ & $28.1 \%$ & $54.3 \%$ & $44.9 \%$ & 0.091 \\
\hline $\begin{array}{l}\text { Mean fasting blood glucose } \\
\text { during } 3^{\text {rd }} \text { trimester }(\mathrm{mg} / \mathrm{dl})\end{array}$ & $90.8 \pm 15.3$ & $85.1 \pm 12.0$ & $91.8 \pm 17.1$ & $93.8 \pm 15.2^{* *}$ & $0.048^{*}$ \\
\hline Delivery (\%) & & & & & 0.991 \\
\hline Normal & $25.0 \%$ & $25.0 \%$ & $25.7 \%$ & $24.5 \%$ & \\
\hline Cesarean & $75.0 \%$ & $75.0 \%$ & $74.3 \%$ & $75.5 \%$ & \\
\hline
\end{tabular}

Abbreviations: BMI, body mass index; OGTT, oral glucose tolerance test.

* Statistically significant differences among BMI categories $(p<0.05) .{ }^{* *}$ Statistically significant difference compared with the normal BMI group $(p<0.05)$.

Table 2 Description of newborn data according to pregestational maternal body mass index

\begin{tabular}{|c|c|c|c|c|c|}
\hline \multirow[t]{2}{*}{ Variables } & \multirow{2}{*}{$\begin{array}{l}\text { Total } \\
n=116\end{array}$} & \multicolumn{3}{|c|}{ Pregestational BMI } & \multirow[t]{2}{*}{ p-value } \\
\hline & & $\begin{array}{l}\text { Normal } \\
n=32\end{array}$ & $\begin{array}{l}\text { Overweight } \\
n=35\end{array}$ & $\begin{array}{l}\text { Obesity } \\
n=49\end{array}$ & \\
\hline Gender (\%) & & & & & 0.538 \\
\hline Male & $47.4 \%$ & $53.1 \%$ & $40.0 \%$ & $49.0 \%$ & \\
\hline Female & $52.6 \%$ & $46.9 \%$ & $60.0 \%$ & $51.0 \%$ & \\
\hline Post-term pregnancy (\%) & $12.9 \%$ & $15.6 \%$ & $8.5 \%$ & $14.3 \%$ & 0.645 \\
\hline GA at birth (weeks) & $38.1 \pm 1.5$ & $38.3 \pm 1.3$ & $37.5 \pm 1.9$ & $38.2 \pm 1.1$ & 0.072 \\
\hline Weight at birth(g) & $3342 \pm 534$ & $3092 \pm 348$ & $3319 \pm 592$ & $3523 \pm 530^{* *}$ & $0.001^{*}$ \\
\hline Macrossomia (\%) & $11.2 \%$ & $0 \%$ & $14.3 \%$ & $16.3 \% * *$ & $0.037^{*}$ \\
\hline LGA (\%) & $25.9 \%$ & $3.1 \%$ & $28.6 \%{ }^{* *}$ & $38.8 \% * *$ & $0.001^{*}$ \\
\hline
\end{tabular}

Abbreviations: BMI, body mass index; GA, gestational age; LGA, large for gestational age.

${ }^{*}$ Statistically significant differences among BMI categories $(p<0.05)$.

** Statistically significant differences compared with the normal BMI group $(p<0.05)$. 
302 Profile of Pregnant Women with Gestational Diabetes Mellitus Tavares et al.

Table 3 Crude and adjusted odds ratios of developing large for gestational age offspring

\begin{tabular}{|c|c|c|c|c|c|}
\hline \multirow[t]{2}{*}{ Variables } & \multicolumn{5}{|c|}{ LGA (Percentil >90) } \\
\hline & $\%$ & $\begin{array}{l}\text { Crude OR } \\
(95 \% \mathrm{Cl})\end{array}$ & p-value & Adjusted OR $(95 \% \mathrm{Cl})$ & p-value \\
\hline \multicolumn{6}{|l|}{ Previous macrossomia } \\
\hline No & 17.5 & Ref. & & Ref. & \\
\hline Yes & 92.3 & $56.7(6.92-463.8)$ & $<0.001^{*}$ & $34.7(4.08-295.3)$ & $0.001^{*}$ \\
\hline \multicolumn{6}{|l|}{ Pregestational BMI } \\
\hline Normal & 3.1 & Ref. & & Ref. & \\
\hline Overweight & 28.6 & $12.4(1.48-103.5)$ & $0.006^{*}$ & $6.53(0.62-68.5)$ & 0.117 \\
\hline Obesity & 38.8 & $19.6(2.41-155.9)$ & $<0.001^{*}$ & $11.6(1.40-95.9)$ & $0.023^{*}$ \\
\hline \multicolumn{6}{|l|}{ Categories of weigth gain } \\
\hline Insufficient & 7.7 & $0.11(0.03-0.45)$ & $<0.001^{*}$ & $0.04(0.01-0.32)$ & $0.001^{*}$ \\
\hline Appropriate & 41.7 & Ref. & & Ref. & \\
\hline Excessive & 29.3 & $0.57(0.22-1.48)$ & 0.368 & $0.39(0.11-1.37)$ & 0.142 \\
\hline \multicolumn{6}{|c|}{ Number of points changed in OGTT (\%) } \\
\hline 1 point & 16.3 & Ref. & & Ref. & \\
\hline 2 points & 27.3 & $1.92(0.67-5.49)$ & 0.327 & $1.05(0.29-3.75)$ & 0.932 \\
\hline 3 points & 37.9 & $3.14(1.04-9.47)$ & $0.037^{*}$ & $1.86(0.38-9.03)$ & 0.440 \\
\hline \multicolumn{6}{|l|}{ Categories changed in OGTT } \\
\hline Only fasting & 13.3 & $0.92(0.16-5.16)$ & 1.000 & $1.11(0.16-7.38)$ & 0.912 \\
\hline Only after dextrose load & 14.3 & Ref. & & Ref. & \\
\hline Fasting and after dextrose load & 37.3 & $3.56(1.29-9.82)$ & $0.020^{*}$ & $3.53(1.17-10.60)$ & $0.024^{*}$ \\
\hline \multicolumn{6}{|l|}{$\begin{array}{l}\text { Mean fasting blood glucose } \\
\text { during } 3^{\text {rd }} \text { trimester }(\mathrm{mg} / \mathrm{dl}) \text {. }\end{array}$} \\
\hline$>95 \mathrm{mg} / \mathrm{dL}$ & 41.7 & $3.07(1.25-7.53)$ & $0.022^{*}$ & $2.67(1.01-7.12)$ & $0.048^{*}$ \\
\hline$<95 \mathrm{mg} / \mathrm{dL}$ & 18.8 & Ref. & & Ref. & \\
\hline
\end{tabular}

Abbreviations: BMI, body mass index; Cl, confidence interval; LGA, large for gestational age; OGTT, oral glucose tolerance test; OR, odds ratio. * Statistically significant differences in the prevalence of LGA $(p<0.05)$. Adjustment of the OR for pregestational BMI variables, previous macrosomia, weight gain categories, mean fasting blood glucose during the $3^{\text {rd }}$ trimester, number of altered points and categories of OGTT.

mean fasting blood glucose in the $3^{\text {rd }}$ trimester $(\mathrm{OR}=4.23$; 95\% CI: $1.25-14.2$ ), and combined change in the OGTT (fasting + after the dextrose load) (OR $=3.53$; $95 \% \mathrm{CI}: 1.17-10.6)$. Insufficient $W G$ reduced the risk for LGA newborns even after adjustment (OR $=0.04 ; 95 \%$ CI: 0.01-0.32) (- Table 3).

The prediction of the occurrence of LGA newborns was estimated using plasma glucose values from the OGTT at 0 , 60 , and 120 minutes ( - Fig. $\mathbf{1}$ ). The data show an area under the curve (AUC) of 0.647 (0.552-0.735) at 0 minutes, of 0.525 (0.413-0.634) at 60 minutes, and of 0.661 (0.567-0.747) at 120 minutes, thus demonstrating that at 0 and 120 minutes were the times that best predicted the occurrence of LGA newborns $(p<0.05)$.

\section{Discussion}

In the present study, the incidence of LGA newborns was of $25.9 \%$; in the literature, this incidence varies from 15 to $45 \%{ }^{19,20}$

Several studies have shown the influence of prepregnancy BMI, as well as of weight gain during pregnancy, on fetal weight. $^{21,22}$ Obesity is currently one of the major public

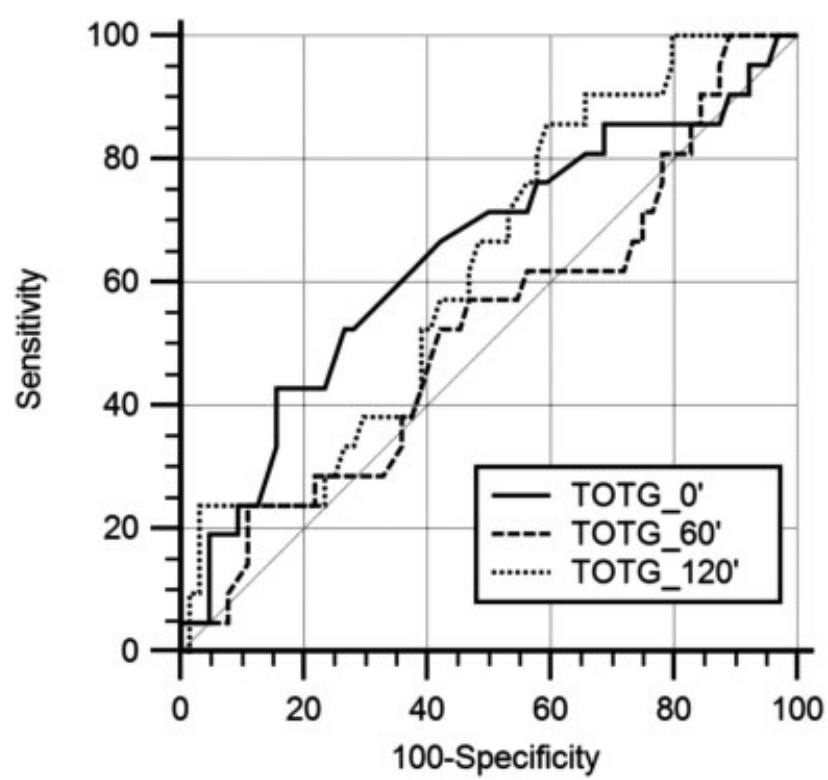

Fig. 1 ROC curve analysis of oral glucose torlerance test values 0 ', 60' and $120^{\prime}$ for prediction of L GA. 
health problems, and its prevalence has been increasing among women of reproductive age. Obesity during pregnancy is associated with an increased risk of gestational hypertension, preeclampsia, fetal macrosomia, and with the need for cesarean section, in addition to the risk of developing GDM $^{23}$ Among Brazilian pregnant women, a BMI $>25 \mathrm{~kg} /$ $\mathrm{m}^{2}$ was related to an increased risk of fetal macrosomia and GDM. $^{13}$

Excessive birthweight is more frequent among obese mothers, regardless of the association with diabetes. ${ }^{24} \mathrm{Ma}-$ ternal obesity is associated with reduced sensitivity to insulin and consequential hyperinsulinemia, which, incremented by high levels of triglycerides, favor excessive fetal growth, regardless of plasma glucose levels. ${ }^{8}$ Some authors state that maternal obesity is the leading factor for the occurrence of LGA newborns. Black et $\mathrm{al}^{23}$ reported a $21.6 \%$ frequency of LGA newborns among overweight or obese pregnant women without GDM, a percentage that rose to $23.3 \%$ when the factors obesity and GDM were combined, whereas the frequency of LGA newborns among women with normal weight and GDM was only $2.9 \%$.

It is estimated that between 65 and $75 \%$ of the women with GDM are also overweight or obese. ${ }^{23}$ In our sample, $72.4 \%$ of the women with GDM were overweight or obese before the pregnancy, and the percentage of LGA newborns was higher among these women, with obesity being an independent risk factor for LGA newborns after the adjusted analysis.

The risk for LGA newborns also appears to increase when WG is considered regardless of prior BMI. ${ }^{19}$ Miao et $\mathrm{al}^{25}$ found a higher incidence of macrosomia among pregnant women with EWG, as did Alberico et al, ${ }^{26}$ who observed that EWG during pregnancy was significantly associated with macrosomia, with a 2.6-fold higher risk in comparison with the recommended WG. ${ }^{25,26}$ Mastella et $\mathrm{al}^{27}$ found that EWG during pregnancy was an independent risk factor for LGA newborns, and that WG during the $3^{\text {rd }}$ trimester was also associated with LGA newborns. In the present study, EWG was not a risk factor for the birth of LGA newborns. The limited sample and possible errors in the self-reported prepregnancy weight may have altered the amount of gained weight.

Although the IOM guidelines for gestational WG are not specific for pregnant women with GDM, they are often applied to them. It is unknown whether the IOM recommendations are appropriate for pregnant women at increased risk of adverse outcomes, or if adjusting these guidelines for women with GDM could improve perinatal outcomes. ${ }^{28}$ It can be assumed that women with GDM require more stringent WG recommendations because of the association of EWG and hyperglycemia and their potentially additive effects that lead to adverse outcomes, such as LGA newborns. ${ }^{28}$

Miao et $\mathrm{al}^{25}$ found that IWG decreased the risk for LGA newborns. This study also showed that WG below that recommended by the IOM was a protective factor for the outcome of LGA newborns, but it is necessary to consider the small sample and the limited statistical power of this analysis.

Additionally, Mastella et $\mathrm{al}^{27}$ found that both AWG and IWG decreased the risk for LGA newborns in pregnant women with GDM. On the other hand, Vesco et $\mathrm{al}^{28}$ noted that WG below recommendations decreases LGA newborns, but increases the risk of SGA newborns. Futhermore, Wong et $\mathrm{al}^{29}$ showed that |EWG was a predictive factor for LGA newborns; however, they noted that changing the IOM criteria to more stringent WG recommendations would not improve perinatal outcomes, including the percentage of macrosomic and LGA newborns.

With the increase of maternal obesity, development of lifestyle interventions may have the potential to improve adverse reproductive outcomes. ${ }^{8}$ Wolff et $\mathrm{al}^{30}$ showed that a simple goal-setting and support program, directed toward a dietary-induced limitation of WG in obese pregnancy, achieved very positive results, including a significant reduction in the fasting serum insulin concentration. In addition, preconceptional counseling of the overweight and obese woman, as well as lifestyle changes, may have the potential to improve adverse reproductive outcomes. ${ }^{24}$ However, a meta-analysis that evaluated different dietary interventions in women with GDM did not observe reduction of LGA newborns among the groups studied. ${ }^{31}$

A previous history of macrosomia is often a risk factor for LGA newborns. ${ }^{32}$ In the present sample, a history of macrosomia was a risk factor for LGA newborns. Heiskanen et al, ${ }^{32}$ in a study comparing 886 pregnancies with macrosomic fetuses with 26,075 pregnancies with AGA fetuses, found a 3.1-fold higher risk of recurrence of macrosomia. ${ }^{32}$ Nkwabong et $\mathrm{al}^{33}$ also showed that a history of fetal macrosomia is a significant risk factor for the recurrence of macrosomia in subsequent pregnancies. Although a history of macrosomia is a nonmodifiable factor, it serves as a marker of major metabolic changes during pregnancy and, in these cases, health care providers should pay attention to potentially influential factors for excessive fetal growth that can be controlled.

With regard to blood glucose levels in the $3^{\text {rd }}$ trimester, high fasting glucose level was an independent risk factor for LGA newborns. Legardeur et $\mathrm{al}^{34}$ observed that fasting blood glucose $\geq 95 \mathrm{mg} / \mathrm{dL}$ doubled the risk for fetal macrosomia. Thus, adequate glycemic control throughout the pregnancy, through diet and/or insulin therapy, especially in the $3^{\text {rd }}$ trimester, should be intense to reduce risks.

The occurrence of LGA newborns was significantly higher in the group of women with combined change in the OGTT (fasting + after the dextrose load), even after the multivariate analysis. Brankica et $\mathrm{al}^{35}$ found that the combination of fasting blood glucose and blood glucose 1 hour after the glucose load in the OGTT was a predictor of occurrence of LGA newborns. Pregnant women exhibiting this combination may be considered at increased risk because of the fact that they have two distinct changes, altered fasting glucose and glucose intolerance, which suggests impairment in two different metabolic pathways associated with the disease, dysfunction of pancreatic $\beta$ cells and insulin resistance. ${ }^{36}$

In the present study, the ROC curve analysis showed that plasma glucose 2 hours after the glucose load in the OGTT was a better predictor for LGA newborns. Silva et al have also identified high levels of plasma glucose at the 2-hour measurement in the OGTT as one of the major independent risk factors for LGA newborns. ${ }^{19}$ Brankica et $\mathrm{al}^{35}$ and Ouzilleau 
et $\mathrm{al}^{37}$ found high levels of fasting blood glucose to be better predictors, whereas Mello et al ${ }^{38}$ showed that 1 -hour blood glucose was the factor most closely associated with LGA newborns. $^{35,37,38}$

\section{Conclusion}

The present study with pregnant women diagnosed with GDM showed that maternal prepregnancy obesity, history of macrosomia, combined change in the OGTT (fasting + after dextrose load), and high-fasting glycemic mean during the $3^{\text {rd }}$ trimester were independent predictive factors for LGA newborns. Weight gain below that recommended by the IOM seems to be a protective factor for the occurrence of LGA newborns, and the need for specific recommendations for pregnant women with GDM may be suggested. However, more studies, with larger numbers of participants, are necessary to validate this finding. Maternal pregestational obesity and high-fasting glycemic mean in the $3^{\text {rd }}$ trimester are modifiable factors, so preventive measures or therapeutic intervention can be implemented to minimize these risk factors. In general, retrospective studies present limitations related to the data obtained. Nonetheless, the present study highlights factors associated with LGA newborns of pregnant women with GDM in Brazil, which may be useful in the management of these patients during pregnancy and in preventing complications for the mothers and for the fetuses.

\section{Collaborations}

All of the authors contributed with the project and data interpretation, the writing of the article, the critical review of the intellectual content, and with the final approval of the version to be published.

Conflicts of Interests

The authors have no conflicts of interests to declare.

\section{References}

1 Metzger BE, Coustan DR. Summary and recommendations of the fourth international workshop - Conference on gestational Diabetes Mellitus. The Organizing Committee. Diabetes Care 1998;21 (Suppl 2):B161-B167

2 Metzger BE, Gabbe SG, Persson B, et al; International Association of Diabetes and Pregnancy Study Groups Consensus Panel. International association of diabetes and pregnancy study groups recommendations on the diagnosis and classification of hyperglycemia in pregnancy. Diabetes Care 2010;33(03):676-682. Doi: 10.2337/dc09-1848

3 American Diabetes Association. Standards of medical care in diabetes-2011. Diabetes Care 2011;34(Suppl 1):S11-S61. Doi: $10.2337 / \mathrm{dc} 11-\mathrm{S} 011$

4 Diagnostic criteria and classification of hyperglycaemia first detected in pregnancy: a World Health Organization Guideline. Diabetes Res Clin Pract 2014;103(03):341-363. Doi: 10.1016/j. diabres.2013.10.012

5 Oliveira JEP, Montenegro RM Junior, Vencio S. Avaliação e tratamento do diabetes mellitus gestacional. In: Oliveira JEP, Montenegro Junior RM, Vencio S, orgs. Diretrizes da Sociedade Brasileira de Diabetes 2017-2018. São Paulo, SP: Clannad; 2017:217-222
6 Siega-Riz AM, King JC; American Dietetic Association; American Society of Nutrition. Position of the American Dietetic Association and American Society for Nutrition: obesity, reproduction, and pregnancy outcomes. J Am Diet Assoc 2009;109(05):918-927. Doi: 10.1016/j.jada.2009.03.020

7 Chu SY, Callaghan WM, Kim SY, et al. Maternal obesity and risk of gestational diabetes mellitus. Diabetes Care 2007;30(08):2070-2076. Doi: $10.2337 /$ dc06-2559a

8 Huda SS, Brodie LE, Sattar N. Obesity in pregnancy: prevalence and metabolic consequences. Semin Fetal Neonatal Med 2010;15 (02):70-76. Doi: 10.1016/j.siny.2009.09.006

9 Mitanchez D, Yzydorczyk C, Simeoni U. What neonatal complications should the pediatrician be aware of in case of maternal gestational diabetes? World J Diabetes 2015;6(05):734-743. Doi: 10.4239/wjd.v6.i5.734

10 Battaglia FC, Lubchenco LO. A practical classification of newborn infants by weight and gestational age. J Pediatr 1967;71(02): 159-163. Doi: 10.1016/S0022-3476(67)80066-0

11 American College of Obstetricians and Gynecologists'. Committee on Practice Bulletins-Obstetrics Practice Bulletin No. 173: fetal macrosomia. Obstet Gynecol 2016;128:e195-e209. Doi: 10.1097/ AOG.0000000000001767

12 Melo ASO, Assunção PGS, Gondim SSR, et al. Estado nutricional materno, ganho de peso gestacional e peso ao nascer. Rev Bras Epidemiol 2007;10:249-257. Doi: 10.1590/S1415-790X2007000 200012

13 Braga CP, Santos FA, Silva EG, Hirakawa HS, Fernandes AAH, Calderon IMP. Relação do ganho de peso, antes e durante a gravidez, com a macrossomia fetal em gestações complicadas pelo diabetes gestacional e hiperglicemia leve. Nutrire Rev Soc Bras Aliment Nutrire 2011;36(01):85-98

14 Di Cianni G, Miccoli R, Volpe L, Lencioni C, Del Prato S. Intermediate metabolism in normal pregnancy and in gestational diabetes. Diabetes Metab Res Rev 2003;19(04):259-270. Doi: 10.1002/dmrr.390

15 Ministério da Saúde. Secretaria de Atenção à Saúde. Departamento de Ações Programáticas Estratégicas. Gestação de Alto Risco: Manual Técnico. 5a ed. Brasília, DF: Editora do Ministério da Saúde; 2012. Available from: http://bvsms.saude.gov.br/bvs/publicacoes/manual_tecnico_gestacao_alto_risco.pdf. Accessed March 10, 2017

16 WHO Expert Committee on Physical Status: the Use and Interpretation of Anthropometry: report of a WHO Expert Committee. WHO technical report series; 854. Geneva, 1995. Available from: https://apps.who.int/iris/bitstream/handle/10665/37003/ WHO_TRS_854.pdf?sequence=1. Accessed February 12, 2017

17 Rasmussen KM, Yaktine AL; Institute of Medicine and National Research Council. Weight Gain During Pregnancy: Reexamining the Guidelines. Washington, DC: The National Academies Press; 2009. Available from: https://www.nap.edu/read/12584/chapter/ 1. Accessed April 10, 2017

18 Villar J, Cheikh Ismail L, Victora CG, et al; International Fetal and Newborn Growth Consortium for the 21stCentury (INTERGROWTH21st). International standards for newborn weight, length, and head circumference by gestational age and sex: the Newborn CrossSectional Study of the INTERGROWTH-21st Project. Lancet 2014; 384(9946):857-868. Doi: 10.1016/S0140-6736(14)60932-6

19 Silva JC, Bertini AM, Ribeiro TE, de Carvalho LS, Melo MM, Barreto Neto L. [Factors related to the presence of large for gestational age newborns in pregnant women with gestational diabetes mellitus]. Rev Bras Ginecol Obstet 2009;31(01):5-9. Doi: 10.1590/ S0100-72032009000100002

20 Kc K, Shakya S, Zhang H. Gestational diabetes mellitus and macrosomia: a literature review. Ann Nutr Metab 2015;66:14-20. Doi: 10. $1159 / 000371628$

21 HAPO Study Cooperative Research Group. Hyperglycaemia and Adverse Pregnancy Outcome (HAPO) Study: associations with maternal body mass index. BJOG 2010;117(05):575-584. Doi: 10.1111/j.1471-0528.2009.02486.x 
22 Badon SE, Dyer AR, Josefson JL; HAPO Study Cooperative Research Group. Gestational weight gain and neonatal adiposity in the Hyperglycemia and Adverse Pregnancy Outcome study-North American region. Obesity (Silver Spring) 2014;22(07):1731-1738. Doi: $10.1002 /$ oby.20742

23 Black MH, Sacks DA, Xiang AH, Lawrence JM. The relative contribution of prepregnancy overweight and obesity, gestational weight gain, and IADPSG-defined gestational diabetes mellitus to fetal overgrowth. Diabetes Care 2013;36(01):56-62. Doi: 10.2337/dc12-0741

24 Ehrenberg HM, Mercer BM, Catalano PM. The influence of obesity and diabetes on the prevalence of macrosomia. Am J Obstet Gynecol 2004;191(03):964-968. Doi: 10.1016/j.ajog.2004.05.052

25 Miao M, Dai M, Zhang Y, Sun F, Guo X, Sun G. Influence of maternal overweight, obesity and gestational weight gain on the perinatal outcomes in women with gestational diabetes mellitus. Sci Rep 2017;7(01):305. Doi: 10.1038/s41598-017-00441-z

26 Alberico S, Montico M, Barresi V, et al; Multicentre Study Group on Mode of Delivery in Friuli Venezia Giulia. The role of gestational diabetes, pre-pregnancy body mass index and gestational weight gain on the risk of newborn macrosomia: results from a prospective multicentre study. BMC Pregnancy Childbirth 2014; 14:23. Doi: $10.1186 / 1471-2393-14-23$

27 Mastella LS, Weinert LS, Gnielka V, et al. Influence of maternal weight gain on birth weight: a gestational diabetes cohort. Arch Endocrinol Metab 2018;62(01):55-63. Doi: 10.20945/2359-3997000000009

28 Vesco KK, Sharma AJ, Dietz PM, et al. Newborn size among obese women with weight gain outside the 2009 Institute of Medicine recommendation. Obstet Gynecol 2011;117(04):812-818. Doi: 10.1097/AOG.0b013e3182113ae4

29 Wong T, Barnes RA, Ross GP, Cheung NW, Flack JR. Are the Institute of Medicine weight gain targets applicable in women with gestational diabetes mellitus? Diabetologia 2017;60(03): 416-423. Doi: 10.1007/s00125-016-4173-3

30 Wolff S, Legarth J, Vangsgaard K, Toubro S, Astrup A. A randomized trial of the effects of dietary counseling on gestational weight gain and glucose metabolism in obese pregnant women. Int J Obes 2008;32(03):495-501. Doi: 10.1038/sj.ijo.0803710

31 Han S, Middleton P, Shepherd E, Van Ryswyk E, Crowther CA. Different types of dietary advice for women with gestational diabetes mellitus. Cochrane Database Syst Rev 2017;2:CD009275. Doi: 10.1002/14651858.cd009275.pub3

32 Heiskanen N, Raatikainen K, Heinonen S. Fetal macrosomia-a continuing obstetric challenge. Biol Neonate 2006;90(02): 98-103. Doi: 10.1159/000092042

33 Nkwabong E, Nzalli Tangho GR. Risk factors for macrosomia. J Obstet Gynaecol India 2015;65(04):226-229. Doi: 10.1007/s13 224-014-0586-4

34 Legardeur H, Girard G, Journy N, Ressencourt V, Durand-Zaleski I, Mandelbrot L. Factors predictive of macrosomia in pregnancies with a positive oral glucose challenge test: importance of fasting plasma glucose. Diabetes Metab 2014;40(01):43-48. Doi: 10.1016/j.diabet.2013.01.008

35 Brankica K, Valentina VN, Slagjana SK, Sasha JM. Maternal 75-g OGTT glucose levels as predictive factors for large-for-gestational age newborns in women with gestational diabetes mellitus. Arch Endocrinol Metab 2016;60(01):36-41. Doi: 10.1590/2359-399700 0000126

36 Tripathy D, Carlsson M, Almgren P, et al. Insulin secretion and insulin sensitivity in relation to glucose tolerance: lessons from the Botnia Study. Diabetes 2000;49(06):975-980. Doi: 10.2337| diabetes.49.6.975

37 Ouzilleau C, Roy MA, Leblanc L, Carpentier A, Maheux P. An observational study comparing 2-hour 75-g oral glucose tolerance with fasting plasma glucose in pregnant women: both poorly predictive of birth weight. CMAJ 2003;168(04):403-409

38 Mello G, Parretti E, Cioni R, et al. The 75-gram glucose load in pregnancy: relation between glucose levels and anthropometric characteristics of infants born to women with normal glucose metabolism. Diabetes Care 2003;26(04):1206-1210. Doi: 10.2337 /diacare.26.4.1206 